\title{
Message from the 2018 Program Chair
}

Published online: 6 December 2018

(C) International Association of Medical Science Educators 2018
Dear Friends and Colleagues,

It is with great enthusiasm that the Program Committee for the 22nd annual meeting of the International Association of Medical Science Educators (IAMSE), held in Henderson, NV, USA, on June 9-12, 2018, presents these conference proceedings.

The 2018 annual meeting was a tremendous success. Meeting registration was sustained when compared to the record number of attendees the prior year in Vermont. This encouraging trend emphasizes the attractiveness of our annual meeting for educational dialog and cutting-edge faculty development. The response to this year's theme, "Integrating Nutrition and Wellness Education in Teaching the Health Sciences" was impressive. The outstanding plenary presentations offered compelling insight into multiple facets of wellness, resiliency and spirituality of students, faculty and staff, and the important role of nutrition education in the health sciences. The high-quality conference sessions, oral presentations, and posters demonstrated the application of these research-derived principles and challenged us to make changes in our own work as educators. Finally, and thanks to the efforts of the Student Professional Development Committee, we benefited from the participation of a record number of students and welcomed them as future colleagues into our conference and organization.

This issue of Medical Science Educator presents to you, our readers, a compilation of plenary speaker presentations in addition to the abstracts from our meeting's oral and poster submissions. The mission of IAMSE is to advance health profession education through teacher development and to ensure that the teaching and learning of medical science continues to be firmly grounded in foundational sciences and the best practices of teaching. This year's meeting exemplified the mission through its offerings of timely and innovative Preconference Workshops, Faculty Development Courses, Plenary Sessions, Concurrent Focus Sessions, Poster Viewing Sessions, and Poster Discussion Sessions. Recipients of the IAMSE Distinguished Career Award for Excellence in Teaching and Educational Scholarship, Early Career Award for Excellence in Teaching and Innovation, Student and Faculty Travel, Oral Presentation, and Poster Presentation awards truly represent the outstanding accomplishments and contributions of our members. In addition, we recognized Adi Haramati, PhD, with the Edward Patrick Finnerty Lifetime Achievement Award for his sustained involvement in and commitment to the advancement of IAMSE. In addition, future education leaders participated in the Essential Skills in Medical Education (ESME) Program and Educational Scholarship Fellowship Program.

IAMSE's members are international leaders, innovators, and scholars in health sciences education. The work presented in this issue represents evidence-informed curricula, instructional strategies, assessment methods, faculty development, and technology for teaching. We hope that they inspire you in your own academic and scholarly efforts. Please join us for our next annual meeting on June 8-11, 2019, in Roanoke, VA, USA. We look forward to seeing you there!

Richard C. Vari, $\mathrm{PhD}$

Chair, 2018 Program Planning Committee

IAMSE President

Publisher's Note Springer Nature remains neutral with regard to jurisdictional claims in published maps and institutional affiliations. 